\title{
Awareness Level of Retail Investors on Stock Market in Chennai City
}

\section{A.Kamaruniza}

\begin{abstract}
The globalization of monetary markets has been increasing the dimensions of retail investor community over the past three decades by providing a good sort of market and investment options. Hence, it makes their investment decisions process more complex. The present study aims to study the awareness of investors on stock market. The data were collected from 100 retail stock market investors of Chennai using structured questionnaire. The analysis is made using percentage and mean value. The study proves that post graduate, professional, high income level investors are aware of investment patterns through friends, neighbors and they yield a good income. The study also reveals that the retail investors are even aware of the fundamental and technical analysis of investment, which helps them for a better and wise investment.
\end{abstract}

\section{Keywords: Stock Market, Investors, Investment Decision.}

\section{INTRODUCTION}

In Asia, Indian stock markets are the oldest one. The record shows that earlier security dealings were meager and obscure in India. Hence, creating awareness about the stock market investment in particular to retail market is necessary to create knowledge of investments in shares and other investment. Further, the awareness creates more knowledge on financial products to the retail investors for decision making, in specific to less educated and to the long term investors. This needs a coordinated approach to convert the awareness into knowledge through advertisement and agent. Securities and Exchange Board of India (SEBI) defines retail investor, whose total investment in equity market is not more than Rs. 2 lakhs per year. Retail investors can be active or passive. Investment in primary market, new issue market and secondary market are done directly by active retail investors.

In India, as per the SEBI guidelines, in order to invest actively in equity market, investors are required to have a Demat Account. This account can be opened only if one has PAN (Permanent Account Number) from the Income Tax department of Government of India.

Revised Manuscript Received on December 5, 2019.

Dr. A.Kamaruniza, Assistant Professor,Pg \& Research, Department Of Commerce. The Quaide Milleth College, Men Medavakkam, Chennai Email Id :Km.Chennai@Gmail.Com
There are some retail investors who may not be active or may not have shifted to dematerialized platform as yet. The figure of such investors will be very small but may not be inconsequential. The investor has to make a choice of investing in a particular company or sector by analyzing different internal factors which might influence the performance of the company. Positive update about a company can increase buying interest in the equity market whereas a negative update release can ruin the scene of any stock. Investors change in their pattern of investment.

\section{RELATED REVIEW OF LITERATURE}

Surbhi Dubey \& Sameer Sharma (2019), "Retail Investors Awareness Towards Stock Market Investment studied that review of literature; sifting of secondary data analysis collected primary data, minute scrutiny of the result, documenting certain facts \& figures applicable to the retail investors of the Indian stock market. The study covers 500 active retail investors taken as a sample of almost 29 million retail investors in India. It was found that there is significant trend regarding statements.

Vijay \& Balanageswara Rao (2018) “A study on investors perception towards Sharemarket in Sharekhan Ltd " viewed that the factors influencing investor's perception are return on investment, market trend or risk, ST profitability, share price, dividend policy, financial performance of the past, company status, standing of the board, current pay packet of the company and expert view.

Sivashakti \& William Robert (2017) “A study on investors' awareness on share market" examined that the Awareness of Investors in Stock Market tells about Age levels of investors above 40 are highly aware compare to other groups. The marital status is highly aware. The educated investor has high awareness and it is significant. Business people have more awareness with the high income level when compare to others. The result shows that the investor's awareness level is high and the company earns the profit.

Banumathy, Azhagaiah (2016), in their study "Investors awareness about investment in stock market" examined that the awareness of investors on stock market investment. The data were collected from 290 stock market investors of Pondicherry using structured questionnaire. The analysis is made using Mann-Whitney $\mathrm{U}$ test and Kruskal-Wallis $\mathrm{H}$ Test. The study proves that there is a significant difference between male and female investors on awareness of stock market investment; there is a significant difference among the age, educational and occupational groups with respect to awareness; there is also a significant difference among the investors of different age and occupational groups, in respect of awareness. 


\section{OBJECTIVES OF THE STUDY}

- To study the demographic profile of the respondents of retail investors on stock market

- To analyze the awareness level of the retail investors on stock market in Chennai city.

\section{RESEARCG METHODOLOGY}

A questionnaire schedule method was adopted to have the information from the actual as well as the potential consumers investing in stock market. The questionnaire highlighted the data identification as well as the note of various constraints faced by the respondents. Random sampling method was adopted for the collection of data. The researcher has used both primary (questionnairemultiple choice and five point scale -87 questions) and secondary data (journals and books) to have clear cut information on the topic. The survey was conducted among 100 investors in different investment category.

\section{STATISTICAL TOOLS}

The information collected by the primary method have been tabulated and analyzed with the help of statistical tools like percentage and mean value (Frequency table) using SPSS Version 16.0.

\section{DATA ANALYSIS AND INTERPRETATIONS}

(A) Demographic Profile of the Retail Investors in Stock Market

Table 1: Demographic Profile of the Retail

\section{Investors}

\begin{tabular}{|c|c|c|}
\hline \multicolumn{2}{|c|}{ Demographic Profile of the Respondent } & Percentage \\
\hline \multirow[t]{3}{*}{ Gender } & Male & 95 \\
\hline & Female & 05 \\
\hline & Total & 100 \\
\hline \multirow[t]{5}{*}{ Education } & School & 8 \\
\hline & Graduate & 22 \\
\hline & Post Graduate & 32 \\
\hline & Professional & 38 \\
\hline & Total & 100 \\
\hline \multirow[t]{5}{*}{ Occupation } & Government & 10 \\
\hline & Private Sector & 38 \\
\hline & Business & 22 \\
\hline & Professional & 40 \\
\hline & Total & 100 \\
\hline \multirow[t]{5}{*}{ Income } & Below 25,000 & 8 \\
\hline & $25,001-50,000$ & 24 \\
\hline & $50,001-75000$ & 32 \\
\hline & Above 75,000 & 36 \\
\hline & Total & 100 \\
\hline \multirow[t]{5}{*}{ Reasons for Trading } & Saving & 10 \\
\hline & Earning & 70 \\
\hline & Investment & 5 \\
\hline & Speculation & 15 \\
\hline & Total & 100 \\
\hline \multirow[t]{4}{*}{ Opinion on Stock } & Wise & 60 \\
\hline & Safe & 20 \\
\hline & Risk & 20 \\
\hline & Total & 100 \\
\hline \multirow[t]{4}{*}{ Willingness to Invest } & Gold & 6 \\
\hline & Property & 34 \\
\hline & Stock & 60 \\
\hline & Total & 100 \\
\hline \multirow[t]{5}{*}{ Investment Pattern } & Equity Shares & 50 \\
\hline & $\begin{array}{l}\text { Preference } \\
\text { Shares }\end{array}$ & 5 \\
\hline & Debentures & 10 \\
\hline & Mutual Funds & 20 \\
\hline & Others & 15 \\
\hline
\end{tabular}

\begin{tabular}{|l|l|r|}
\hline \multirow{4}{*}{ Mode of Information } & Total & 100 \\
\hline \multirow{5}{*}{ Mode of Trade } & Media & 42 \\
\cline { 2 - 3 } & Internet & 28 \\
\cline { 2 - 3 } & Business & 16 \\
& Channel & 14 \\
\cline { 2 - 3 } & Broker & 100 \\
\cline { 2 - 3 } & Total & 32 \\
\hline \multirow{5}{*}{ Motivation } & BSE & 38 \\
\cline { 2 - 3 } & NSE & 23 \\
\cline { 2 - 3 } & Both (a) and & 07 \\
\hline (b) & 100 \\
\cline { 2 - 3 } & Others & 5 \\
\cline { 2 - 3 } & Total & 22 \\
\hline & Family & 52 \\
\hline & Members & 21 \\
\cline { 2 - 3 } & Neighbours & 100 \\
\cline { 2 - 3 } & Friends & \\
\cline { 2 - 3 } & Self Motivated & \\
\cline { 2 - 3 } & Total & \\
\hline
\end{tabular}

(Source: Computed)

Chart 1: Chart showing the Demographic Profile of the Retail Investors

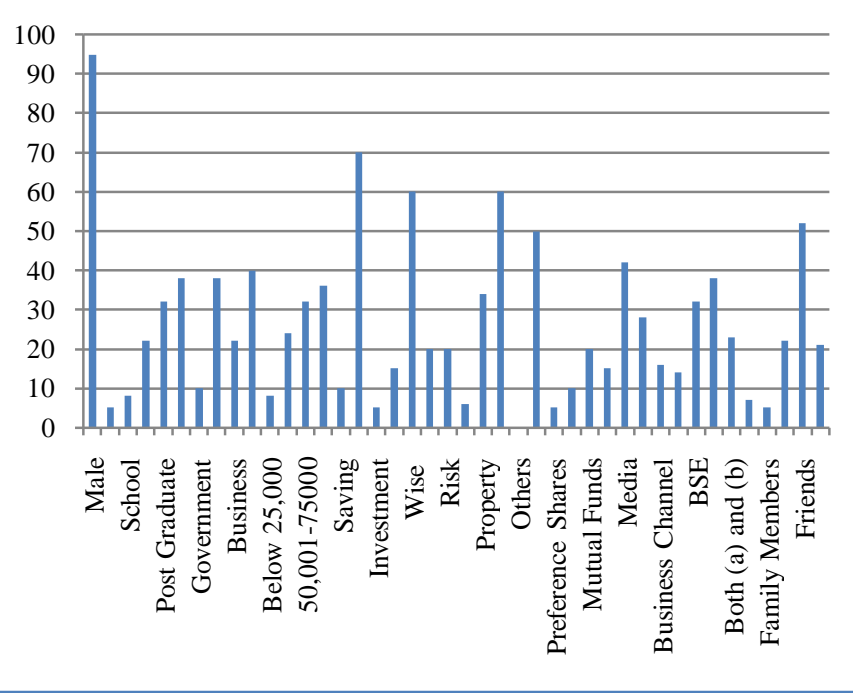

- Interpretation

From the above table, it is interpreted that male investors (95\%) are found to the high. Further, professionally qualified investors invest (40\%) high and the next is private sector investors $(38 \%)$ than the graduates, whose income level is more than 75,000 . Subsequently, they found the investments to be wise in their earnings. They invest more on stock and equity shares. They would like to invest more on stock $(60 \%)$ and property $(34 \%)$ from the profit gained in stock market. The investors are highly aware through the media $(42 \%)$ and motivated through friends (52\%), neighbors etc., and their mode of trade is also found to be both in NSE and BSE.

\section{- Inference}

Demographic profile of the retail investors infers that, male are more engaged in trading, with professional knowledge and skill and with high income level. The knowledge on share market is gained from friends, neighbors, internet etc.

(B) Awareness Level of Retail Investors on Stock Market

Published By:

Blue Eyes Intelligence Engineering

15 \& Sciences Publication 
Table 2: Retail Investors Awareness Level on Stock Market

\begin{tabular}{|c|c|c|c|c|}
\hline Si.No. & Statement & $\begin{array}{c}\text { Cumulative } \\
\text { Mean } \\
\text { Score }\end{array}$ & $\begin{array}{c}\text { No. Of } \\
\text { Variable }\end{array}$ & $\begin{array}{c}\text { Average } \\
\text { Score }\end{array}$ \\
\hline 1 & $\begin{array}{l}\text { Knowledge of technical } \\
\text { analysis }\end{array}$ & 50.54 & 12 & 4.21 \\
\hline 2 & $\begin{array}{l}\text { Knowledge of Fundamental } \\
\text { Analysis }\end{array}$ & 63.90 & 14 & 4.56 \\
\hline 3 & $\begin{array}{l}\text { Awareness about Nifty and } \\
\text { Sensex }\end{array}$ & 36.20 & 10 & 3.62 \\
\hline 4 & Websites & 74.81 & 15 & 4.98 \\
\hline 5 & Return on investment & 58.36 & 12 & 4.86 \\
\hline 6 & $\begin{array}{l}\text { Communication between the } \\
\text { investors and company }\end{array}$ & 48.75 & 13 & 3.75 \\
\hline
\end{tabular}

(Source: Computed)

Chart 2: Chart showing Awareness level of investors

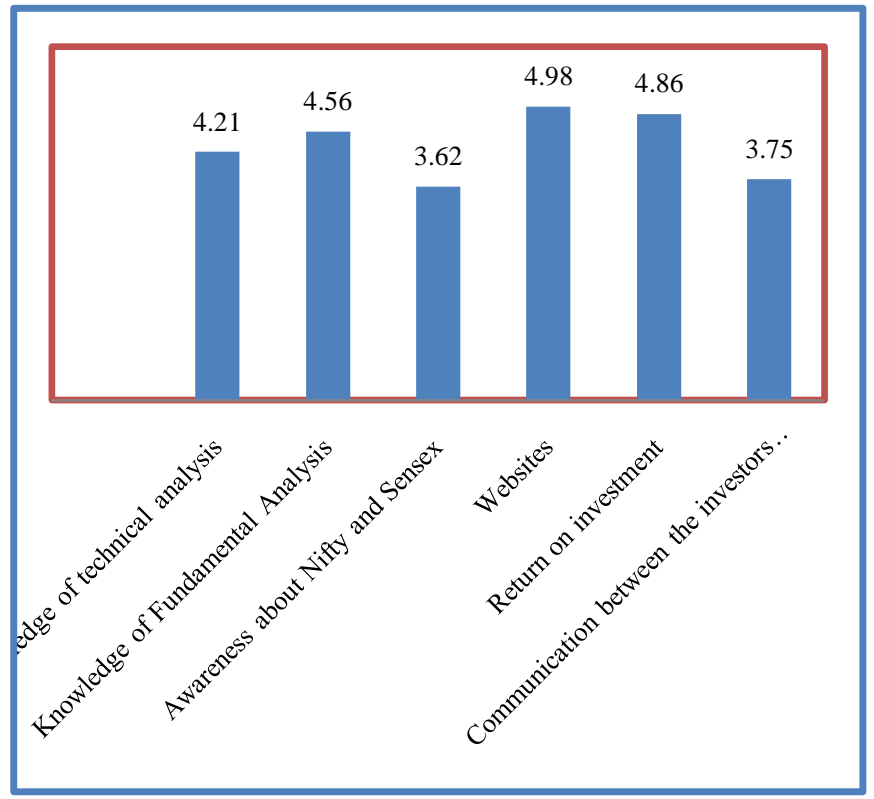

\section{- Interpretation}

The table interprets that, the mean value of technical analysis shows a value of 4.21 . The investors even have knowledge on fundamental analysis of 4.56. It shows that investors has a good knowledge on calculation of rate of risk, investment etc. It also shows that, the more information is gathered from the websites 4.98 mean value. The mean value even shows that the return on investment is high and communication needs to be development.

\section{- Inference}

The able table infers that, the investors are aware about the pattern of investment, fundamental, technical, Sensex, Nifty and they have a good return on investment as they have good awareness level.

\section{LIMITATION OF THE STUDY}

Limitations of the study are as follows:

(a) Investors are large in numbers, so the present study covers only few retail investors.

(b) Retail investors belonging to Chennai city only.

\section{RESULTS AND DISCUSSION}

Investors' awareness is the process by which the investors improve their understanding of the financial markets, products, concepts and risks. Financial literacy helps an investor to make an informed judgment about investments; keeping in mind the specific goals of investing. Stock market corrections have affected the trust of investors. The study reveals that professional with high education are highly influenced with the investment ideas. Further, they are associated with the media and friends to get the information about the fundamental and technical analysis in investment as a motivation for the earnings. The investors expect more communication from the investing companies during their trading. Therefore, the study reveals that retail investor has high awareness level about the investment patterns.

\section{REFERENCE}

1. Surbhi Dubey \& Sameer Sharma (2019), "Retail Investors Awareness Towards Stock Market Investment"e :ISSN 24549916,5,2019.

2. Vijay \& Balanageswara Rao (2018) "A Study On Investor Perception Towards Sharemarket In Sharekhan Ltd. International Journal of Trend in Scientific Research and Development (IJTSRD) International Open Access Journal | www.ijtsrd.com ISSN No: 2456 - $6470 \mid$ Volume - 2 | Issue - 6 | Sep - Oct 2018

3. Sivashakti \& William Robert (2017) In "A Study On Investors Awareness On Share Market”. Vol-3 Issue-6 2017 IJARIIEISSN(O)-2395-4396.

4. Banumathy, Azhagaiah (2016), In Their Study "Investors Awareness About Investment In Stock Market". Pacific Business Review International, Volume 8, Issue 11, May 2016.

\section{AUTHOR PROFILE}

Dr. A.Kamaruniza, Assistant Professor,Pg \& Research Department Of Commerce The Quaide Milleth College For Men Medavakkam, Chennai 100 Email Id :Km.Chennai@Gmail.Com 